\title{
Mutual Indwelling
}

\section{A. J. COTNOIR}

Perichoresis — sometimes translated 'co-inherence' or 'mutual indwelling' — is an important concept in Christian theology, central to many historical and contemporary understandings of the doctrine of the Trinity. The persons of the Trinity are said to indwell one another, and this indwelling constitutes an intimate relationship between them. Perichoresis is used in different theological frameworks to ground various other aspects of the doctrine of the Trinity, such as the unity or oneness of the Trinity or the communication of attributes between the divine persons. This notion of interpenetration or mutual indwelling can seem confusing or even perhaps paradoxical, but I will suggest that a mereological understanding of this concept can serve to illuminate perichoresis. To be more precise: I argue that the relation of mutual parthood can provide a coherent model of mutual indwelling of the persons on the Trinity.

The concept of mutual indwelling has its roots in the biblical texts, primarily in the Gospel of John, where Jesus is quoted saying, "[...] you may know and understand that the Father is in me, and I in the Father" (John I0:38). Similarly, Jesus requests in John I0:9-I I, "Believe me when I say that I am in the Father and the Father is in me."1

Following others, ${ }^{2}$ we may distinguish two versions of the concept: person-perichoresis and nature-perichoresis. Person-perichoresis regards the perichoretic relation(s) that holds within the Trinity between the three persons (Father, Son, and Spirit). Nature-perichoresis regards the perichoretic relation that holds within the hypostatic union between the two natures (human and divine) of the incarnate Son.

As Crisp [28, p. I 2 I-I 23] (following Prestige [85] and others) notes, perichoresis was first used by Gregory of Nazianzen in the 4th century A.D. followed by Maximus the Confessor. It

\footnotetext{
${ }^{1}$ In fact, Jesus extends some form of mutual indwelling to his disciples when he promises the Spirit of truth who "will be in you" in John I4:I7-20: "I am in the Father, and you are in me, and I am in you." (Cf. John I7:2 I-23).

${ }^{2}$ Swinburne [99, p. 209, n. 20], Crisp [28, p. I2I]
} 
wasn't until John of Damascus in the 7 th century A.D. that the concept was applied to the Trinity alongside the notion of 'interpenetration'. ${ }^{3}$ By the time of the Council of Florence in I44I A.D. person-perichoresis had been fully incorporated into orthodoxy:

Because of this unity the Father is wholly in the Son and wholly in the Holy Ghost, The Son is wholly in the Father and wholly in the Holy Ghost, the Holy Ghost is wholly in the Father and wholly in the Son. ([8o, p. 7I $]$ )

But the concept of mutual indwelling is intuitively puzzling. According to all the usual ways of conceiving of 'indwelling' or 'being in', it seems conceptually incoherent to think that two persons could be in each other. If I am in my house, then my house is not in me. This just seems to be a fact about the metaphysics of being in. The puzzling nature of mutual indwelling was already made plain in the mid-4th century A.D. by Hilary of Poitiers who writes:

[It] confuse[s] many minds, and not unnaturally, for the powers of human reason cannot provide them with any intelligible meaning. It seems impossible that one object should be both within and without another, or that $[\ldots]$ these Beings can reciprocally contain One Another, so that One should permanently envelope, and also be permanently enveloped by, the Other, whom yet He envelopes. [...] We must think for ourselves, and come to know the meaning of the words, 'I in the Father, and the Father in Me': but this will depend upon our success in grasping the truth that reasoning based upon Divine verities can establish its conclusions, even though they seem to contradict the laws of the universe. (De Trinitate, iii, I, in [9I, p. 234])

The underlying conception does seem impossible, contradicting the metaphysical principles of the universe. And yet despite its widespread use in theology (perhaps even its overuse ${ }^{4}$ ), the concept

\footnotetext{
${ }^{3}$ See Twombly [107] for a full examination of John of Damascus on perichoresis.

${ }^{4}$ cf. Kilby [59], Otto [8I]
} 
of mutual indwelling has received comparatively little philosophical attention; ${ }^{5}$ and the puzzle regarding its conceptual coherence is rarely examined. ${ }^{6}$ But without such analysis, there is the real danger that an important theological concept be rejected as unintelligible, or perhaps dismissed as 'divine mystery'. ${ }^{7}$ But even the greatest and most difficult divine mysteries (e.g. the Trinity or the hypostatic union) have been subject to unending philosophical analysis. We can and should agree with Crisp [28, p. I 20] that trying to better understand mutual indwelling is a worthwhile enterprise, even if a complete understanding is "forever beyond us" (van Inwagen [Io8, p. 243]).

This article is an attempt to alleviate some of the puzzlement; I argue that a current formal theory of an ordinary conception of 'being in' allows for mutual indwelling. In $₫$ I, I examine a range of possible proposals for modeling the perichoretic relationship, arguing that they will not succeed. In $\$_{2}$, I suggest a mereological way of understanding 'being in’, by analogy with independently motivated examples in contemporary metaphysics. Because I am understanding perichoresis as a kind of parthood, it is crucial to show how such an understanding relates to the doctrine of divine simplicity. In $\S_{3}$, I argue that this proposal does not conflict with simplicity, surprisingly, but instead affirms it. I conclude in $\S_{4}$, by discussing how mutual indwelling relates to the concepts of unity (inseparability) and identity (indiscernibility).

\footnotetext{
${ }^{5}$ The concept has seen use in philosophical theorizing on the Trinity, (e.g. Davis [32,33], Hasker [52, ch. 25], Williams [ I I 2]), but almost nothing by the way of analysis.

${ }^{6}$ The situation leads Tuggy [io5] to complain:

But one suspects that all proponents mean by periochoresis in this context is 'whatever it is which makes divine persons combine to make a further person'. Even if it is true that the Father, Son, and Holy Spirit 'metaphysically interpenetrate' (whatever this means) [...] such metaphors simply hide an unintelligible claim. ([I05, p. I70f])

${ }^{7}$ Hilary of Poitiers seemed to think philosophical reflection would not be of any help:

This is a problem which the wit of man will never solve, nor will human research ever find an analogy for this condition of Divine existence. But what man cannot understand, God can be. I do not mean to say that the fact that this is an assertion made by God renders it at once intelligible to us. (De Trinitate, iii, $\mathrm{I}$, in [9I, p/234])
} 


\section{Varieties of 'Being In'}

Several different philosophically robust concepts of 'being in' are available. I want to distinguish two main groups: the predicational concepts and the containment concepts. Firstly, for the class of predicational concepts, the relata of 'being in' are objects on the one hand and entities of a higher ontological category on the other. A paradigm case is the instantiation relation holding between an object and a property. This is a kind of 'being in', as when an attribute is 'present in' the object it is true of. There is also the taxonomical relation of kind-membership, as when something is 'one of' or 'among' the $F$ s, for some suitable kind $F$. Similarly, there is the relational 'in', as when a two people are said to be 'in love' or 'in a marriage' by virtue of each of them bearing the appropriate relation to one another.

Secondly, there is a class of containment concepts. Paradigm examples of a containment concepts are set-theoretic such as 'being a member of', or 'being a proper subset of'. Similarly, we have plural locutions of 'being one of' or 'being a member of' a plurality of objects, as when I refer to 'one of my children' or 'a member of the Beatles'. Perhaps most centrally, we have locational concepts of being in, involving an entity spatial location. Finally, there is also the mereological conception of containment, namely parthood, as when an object is in another by being a part of it.

One may attempt to understand perichoresis in terms of predicational conceptions of 'being in'. I won't have much to say against such attempts as the main aim of this paper is to explore to what extent we can make sense of mutual indwelling in terms of containment conceptions of 'being in'. But here is a reason to be dissatisfied with the predication conceptions. It is initially plausible that the person-perichoretic relation should be understood as holding between the persons of the Trinity, who are themselves of the same ontological category. Predicational conceptions of 'being in', however, are always trans-categorical - they hold between entities of different ontological type. ${ }^{8}$ And this rules out a straightforward application of instantiation or

\footnotetext{
${ }^{8}$ This is clear enough when we are dealing with first-order entities like objects or persons and their properties which are second-order; and this is all that really matters for the point being made here. Things are a little more contentious
} 
kind-membership. ${ }^{9}$ That is, the persons are said to be in each other, they are not both (individually) 'in $F$ for some property or kind $F$. Similar considerations tell against the relational 'in': it is by virtue of some third relation $R$ between the persons (e.g. Heloise loving Abelard and Abelard loving Heloise) that we say they (jointly) are 'in $R$ ' (e.g. 'Heloise and Abelard are in love' or 'Heloise is in love with Abelard' etc.). ${ }^{10}$ As a result, the relevant sort of 'being in' would not a relation between the persons, but rather it would be relation between the persons and a some relation in a higher ontological category.

None of this is dispositive against predicational concepts; ${ }^{11}$ but I think it does provide a pro tanto motivation for exploring containment conceptions thoroughly.

In the remainder of this section, I consider each of the containment conceptions of 'being in' that are best understood; indeed, each has a formally precise theoretical foundation. I begin by arguing against set-theoretic and plural conceptions. I then consider the locational conception. Finally, I then settle on the mereological conception as my key point of departure. I will argue that there is a viable philosophical theory of parthood, complete with a coherent and consistent formalization, that allows for mutual parts — distinct entities that are parts of each other. Such a view can make sense of a perichoretic relation according to which it is absolutely coherent to affirm that the three persons of the Trinity are 'in' the others.

\section{I.I Containment}

Set theory is the paradigm case of formally developed conception of 'being in'. Sets are abstract (mathematical) collections which have members or elements; elements of a set are in sets by virtue

when we are dealing with higher-level entities like properties and propositions, which presumably can themselves can have properties. The standard view is that any properties of second-order properties must be third-order, and so of a different ontological kind. But of course the standard view might be rejected.

${ }^{9}$ But see $\$ 4$. I.

${ }^{10}$ Linguistically speaking, the prepositional 'in' typically requires the nominalization of the given relation to serve as a its complement. But this should not be taken to mean this sort of 'being in' is a relation between two first-order objects.

${ }^{11}$ One might, for example, put forward a relational view according to which Jesus is 'in union with' the Father and the Father is 'in union with' the Son. Here the relevant $R$ is the perichoretic relation of unity itself, and the apparent symmetry of 'being in' is explained away. I will not explore this proposal further; as my aim in this paper is to take the symmetry of 'being in' seriously. 
of the membership relation Pure sets have nothing but other sets among their members, or their members' members, etc. These are purely abstract. Impure sets can contain concrete objects (called urelements) as members. Though they contain concrete urelements, impure sets are still abstract.

This fact is a problem for modeling mutual indwelling: sets are abstract objects even when its members are concrete. In the case of perichoresis, to model the claim that each person of the Trinity is in the others, we would need to have it each person is an abstract object in order to be capable of having members. But this would (should!) be objectionable to those who think God is a concrete (even if non-material) entity. ${ }^{12}$ Of course, it is not unusual for the purposes of model theory to use set-theoretic entities and relations to represent concrete entities and relations; but for our purposes (i.e. the philosophical explication of a puzzling concept) the explanatory value of doing so seems dubious. ${ }^{13}$

The second main containment conception of 'being in' is found in plural logic. Pluralities are somewhat like sets; they are governed by a membership relation 'is one of': when $x$ is one of the $X \mathrm{~s}$ we can think of $x$ as being contained in the $X \mathrm{~s}$ (e.g. Ringo is one of the Beatles). There are a couple of main differences between sets and pluralities: firstly, pluralities are thought to be concrete when their members are. So for our purposes, pluralities avoid the main problem with sets. Secondly, pluralities are thought to be multiplicities whereas sets are thought to be singular entities (e.g. my children are many; they are not some singular entity).

But this latter difference is also the main problem with plural understandings of mutual in-

\footnotetext{
${ }^{12}$ See Leftow [64] for related discussion, albeit aimed at views in which essences are abstracta and God is identical to God's essence.

${ }^{13}$ In any case, there are other difficulties. The membership relation of Zermelo-Frankel set theory $(Z F)$ is not a good model for 'being in' because of the axiom of foundation which entails that there can be no cycles or loops in the set membership relation. (See e.g. Theorem $7 \mathrm{X}$ in [39, p. 206].) Crucially it cannot be that $X$ is in $Y$ and $Y$ is in $X$ for any sets $X$ and $Y$.

$Z F$ and its descendants are not the only set theories, however. There are a number of set theories in which the axiom of foundation fails. Nonwellfounded set theories or hyperset theories replace the axiom of foundation with variations of an Anti-Foundation Axiom which force there to be sets whose membership relation cycles back on itself (Barwise and Moss [ı]). For example sets like $A=\{B\}$ and $B=\{A\}$ are perfectly consistent (Aczel [I]). Non-wellfounded set theories might provide a formal setting amenable to modeling a perichoretic relation of 'being in' — it may even show that there is a coherent notion of 'being in' that allows for mutual indwelling. But given their exotic character and the lack of philosophical familiarity, doing so would serve little explanatory use.
} 
dwelling. The claim that Son is 'one of' the Father will only be coherent on the assumption that the Father is a multiplicity — that he is a plurality. That's intuitively and theologically problematic, as the Father is an individual person. ${ }^{14}$ Moreover, the Father and the Son would both have to be multiplicities (because the indwelling is mutual), and hence the 'is one of' relationship would not apply. ${ }^{15}$

The third main containment conception of 'being in' can be found in logics of location (Parsons [82], Casati and Varzi [2I]). Theories of location analyze the relation that objects have to the spatio-temporal regions they occupy. Since regions may be contained in other regions, the objects that have those locations may 'inherit' a kind of containment. So, one might define a relation of 'being in' as follows: $x$ is 'in' $y$ if and only if the location of $x$ is a subregion of the location of $y$. This relation is perfectly compatible with mutual indwelling, since $x$ is in $y$ and $y$ is in $x$ merely implies that $x$ and $y$ have identical locations, not that $x$ and $y$ themselves are identical. So co-location could serve as a model of mutual indwelling.

This kind of containment solves the problems with previous notions; after all spatial containment relates one concrete object to another. However, if applied as a model of perichoresis, it commits us to certain requirements on the locations of the persons of the Trinity that are controversial. At the minimum, it requires that the persons of the Trinity have spatial locations, which raises a host of controversial issues about God's relation to spacetime. For example, Hasker [52, p. 242] claims the divine persons cannot be co-located because God is non-spatial. By contrast, traditional considerations surrounding God's omnipresence (Inman [55]) can yield further

\footnotetext{
${ }^{14}$ Perhaps, one could attempt to avoid this by arguing that each person of the Trinity is both one and many. In fact, some who endorse plural logic also argue additionally for many-one identities (see Cotnoir and Baxter [25]). Manyone identity might seem to be precisely the sort of view Trinitarians need (as argued by Bohn [I4]), but it leads to unorthodox claims like 'there is one God and many Gods' (see Kleinschmidt [6I] for compelling arguments against this view). In any case, it seems as though we should be able to model perichoresis without being forced to the view that each person is a multiplicity.

${ }^{15}$ Of course we can generalize the one-many 'is one of' relation to a many-many 'are among' relation defined as follws: the $X_{\mathrm{s}}$ are among the $Y_{\mathrm{s}}$ iff every member of the $X_{\mathrm{s}}$ is a member of the $Y_{\mathrm{s}}$ (e.g. my children are among the schoolchildren). But this still won't allow mutual amongness since the 'among' relation between pluralities is standardly thought to be antisymmetric: if the $X s$ are among the $Y_{s}$ and $Y_{s}$ and then $Y_{s}$ are among the $X_{s}$ then $X s=Y_{s}$. That's because, like sets, pluralities are individuated extensionally: the $X \mathrm{~s}$ and $Y_{\mathrm{s}}$ are identical whenever they have exactly the same members.
} 
conflicts.

\section{I.2 Mereology}

To sum up, we are after a kind of 'being in' relation such that the relata are neither abstracta nor multiplicities. We want a containment relation which holds between a concrete object and another unitary concrete object, and which doesn't require spatial locations for these objects. Fortunately, there is a formal theory of just such a relation - mereology.

Mereology is the formal theory of parts and wholes; it aims at a precise account of the parthood relation. Here 'parthood' is to be understood as the general relation holding between entities and their components, no matter what sort of things they are. For example, the keyboard is part of my computer, my fingers are parts of my hands which are parts of me, the number ' 2 ' is part of the function ' $2 \mathrm{x}+3$ '. So, the relata of parthood can be either concrete or abstract.

There are a number of mereological theories in the literature, but according to so-called 'classical mereology', the parthood relation is what is known as a partial order. That is, the axioms of this theory (typically) contain the following three principles governing parthood. ${ }^{16}$

Reflexivity For all $x, x$ is part of $x$.

Antisymmetry For all $x$ and $y$, if $x$ is part of $y$ and $y$ is part of $x$, then $x$ and $y$ are identical.

Transitivity For all $x, y$, and $z$, if $x$ is part of $y$ and $y$ part of $z$, then $x$ is part of $z$.

Here I have followed standard procedure using 'parthood' as a relation that allows for identity to be a limit case. The strict notion, incompatible with identity, is called 'proper parthood'. Pretty clearly, antisymmetry rules out mutual indwelling between distinct entities; it forces parthood to be asymmetric in a way that is compatible with only the symmetries of identity.

Recently, however, the antisymmetry of parthood has come under fire. Philosophers have put forward a number of purported counterexamples. Consider the Aleph, a strange object found in

\footnotetext{
${ }^{16}$ Of course there are other axioms too. I say 'typically' only because there are different axiomatizations of classical mereology, some of which have these principles as theorems.
} 
the basement of Beatriz Viterbo's house in Borges' story [I 5, p. I 5 I]:

I saw the Aleph from all points. I saw the earth in the Aleph and in the earth the Aleph once more and the earth in the Aleph ....

Sanford [90] mentions this case to suggest that the naïve notion of parthood does not require antisymmetry. As he notes, Borges uses the 'in' of containment and suggests that whatever the Aleph contains is part of it. Consider a passage in the Upanishads that outlines the structural relations between Brahman and persons:

In the center of the castle of Brahman, our own body, there is a small shrine in the form of a lotus-flower, and within can be found a small space. [...] This little space within the heart is as great as this vast universe. The heavens and earth are there, and the sun, and the moon, and the stars; fire and lightning and winds are there; and all that now is and all that is not; for the whole universe is in Him and He dwells within our heart. (Chandogya Upanishad, \$8.1, in [7 I, p. I 20])

Other examples can be found in the from the Huayan school of Chinese Buddhism such as the 'Net of Indra' - a net of jewels that stretches infinitely in every direction, but in which each jewel is contained in every other, symbolizing the interconnectedness of the universe. ${ }^{17}$

In the recent philosophical literature, a structurally similar example has been put forward by Tillman and Fowler.

Suppose that the universe exists [...] a thing such that absolutely everything is a part of it. [...] Assuming there is a unique such thing, let's name it $U$. According to a popular view of semantic content, ' $U$ exists' semantically encodes a singular, structured proposition that has $U$ itself as a constituent as well as the property of existing. By hypothesis, this proposition is a proper part of $U$. But $U$ is in turn a proper part of the relevant proposition. [103, p. 525]

\footnotetext{
${ }^{17}$ See Jones [58] and Priest [86, ch. II ].
} 
Tillman and Fowler take this as evidence that parthood must fail to be antisymmetric, a point made also by Yablo [I I 4, p. I43]. ${ }^{18}$

A final example involves a time-travel case from Kleinschmidt [60]. ${ }^{19}$ Clifford is a dog-shaped statue which was made partly of other statues, including Kibble—a small statue of a biscuit. But Kibble, too, is made partly of other statues, including a time-traveling future version of Clifford himself, suitably reduced in size. As a result, it would seem as though Kibble is a part of Clifford and has Clifford as a part.

All of the above examples are somewhat exotic, requiring some dubitable metaphysical assumptions (the possibility of time travel, the structured view of propositions with constituents as parts). But it should be clear that some philosophers have rejected the 'classical' view that parthood is a partial order. In the next section, I will claim that in fact there are many perfectly ordinary cases of parthood that fail to validate antisymmetry. Indeed, there are viable mereological theories that do not contain antisymmetry as an axiom or theorem.

\section{An Analogy: the Statue and the Clay}

To explain how a theory of parthood could allow for ordinary cases of mutual parts, I want to draw on a standard example from contemporary metaphysics: the statue and the clay it is made from. One major view among metaphysicians is that the statue and the clay are distinct entities by virtue of their being discernible from one another. By 'distinct' here, I mean non-identical, where identity is to be understood in the standard first-order sense. That is, identity is the unique reflexive, transitive, and symmetric relation that satisfies the Indiscernibility of Identicals:

Indiscernibility of Identicals For all (qualitative) properties $F$, if $x$ is identical to $y$, then $F x$ if and only if $F y$.

\footnotetext{
${ }^{18}$ Similar cases regarding parts of propositions are discussed in Cotnoir [22], Gilmore [47], and Merricks [74, pp. I66-I67]

${ }^{19}$ Similar cases have been proposed and discussed in Daniels [30], Eagle [35], Effingham [37], Effingham and Robson [38], Gilmore [49, 45], and Smith [98].
} 
The clay and the statue are frequently thought to be discernible: for example, the clay but not the statue can survive squashing; the statue might be Romanesque, whereas the clay is not; the statue might be badly made where as the clay is not; the clay may be of poor quality but the statue might be of very high quality, etc. ${ }^{20}$ So we may conclude that they are non-identical. ${ }^{21}$

But though they are distinct, they still are completely spatially coincident and are made of the same material parts. This conflicts with the controversial criterion for the identity of objects called mereological extensionality according to which any two composite objects with all the same proper parts are identical.

Classical mereology is extensional in precisely this way; it stipulates that objects are individuated by their parts. If two objects are mereologically equivalent, then they are identical. As a result, classical mereology forces on us the conclusion that objects which are mereologically indiscernible are indiscernible tout court. That is a strong conclusion, indeed.

There are however formal mereologies in the recent literature which reject extensionality, and they have recently been gaining traction.

\section{I Two Kinds of Non-Extensional Mereology}

Non-extensional mereologies fall into two kinds. The first are unsuppplemented mereologies, which reject supplementation principles like the following: ${ }^{22}$

Weak Supplementation If $x$ is a proper part of $y$, there is some part of $y$ that is disjoint from $x$.

(Here, by 'disjoint' I mean that they do not overlap, i.e. the two objects have no parts in common.) This principle gives voice to the intuitive thought that if an object has a proper part it should also have some other part, particularly one which does share any parts with the other. Supplementation principles are extremely plausible, and play a number of important roles in formal mereology.

\footnotetext{
${ }^{20}$ See e.g. Johnston [56] and Fine [4I]. For an overview of such arguments, and relevant references, see [III], Magidor [69], Paul [83], and Blatti [I I].

${ }^{21}$ Whether such properties that discern the statue and clay are themselves qualitative is controversial.

${ }^{22}$ See e.g. Gilmore [48].
} 
The second kind of non-extensional mereology are mutual parts mereologies; they reject the antisymmetry principle for parthood. On such a view, the statue and the clay, though distinct, are part of each other. This view was first defended by Thomson [I I, IO2] and more recently defended by Cotnoir [26]. The statue and the clay, and any other cases of mereologically coincident objects, are perfectly ordinary, non-exotic cases of mutual parthood.

Given the antecedent plausibily of non-extensionalism, it is worth taking the time to make the case that mutual parts mereologies have advantages over unsupplemented mereologies for this purpose. Sider [95, p. I55] argues that if the statue and its matter share the same parts then they must be mutual parts. His argument relies on another mereological principle, called Strong Supplementation.

Strong Supplementation If $x$ is not part of $y$, there is some part of $x$ that is disjoint from $y$.

Since the statue and its clay share all their parts in common, there cannot be a part of one that does not overlap the other, and hence by (the contrapositive of) the above principle, both are parts of one another.

Recently, other arguments have been put forward in favor of mutual parthood anti-extensional mereology. Cotnoir [23] puts forward a number of arguments against unsupplemented mereologies by outlining the key roles supplementation principles play in formal theories of mereology, in addition to arguing that a mutual parts mereology is the best anti-extensional mereology compatible with universalism.

There is a sense in which antisymmetry just is an extensionality principle for parthood. Compare three main forms of extensionality:

Extensionality of Proper Parthood If $x$ and $y$ are composite objects with all and only the same proper parts, then $x=y$.

Extensionality of Overlap If $x$ and $y$ overlap all and only the same things, then $x=y$.

Extensionality of Parthood If $x$ and $y$ have all and only the same parts, then $x=y$. 
All such principles assert an identity between objects that share certain mereological properties. Antisymmetry has the same form, asserting an identity between mutual parts. In fact, if $a$ is part of $b$ and $b$ is part of $a$, by transitivity we know that every part of $a$ is part of $b$ and vice versa. Hence, in the presence of transitivity, antisymmetry is equivalent to the extensionality of parthood.

In short, anyone who is sympathetic to non-extensionalism for material objects ought to take mutual parthood mereology as a serious contender. And since parthood is one sort of containment relation between objects (including concrete objects), it is a good candidate for modeling mutual indwelling.

\subsection{A Formal Theory of Mutual Indwelling}

Here then is an axiomatization of a mereology that allows for mutual parthood.

Reflexivity For all $x, x$ is part of $x$.

Transitivity For all $x, y$, and $z$, if $x$ is part of $y$ and $y$ is part of $z$, then $x$ is part of $z$.

Strong Supplementation If $x$ is not part of $y$, then there is some $z$ that is part of $x$ that is disjoint from $y$.

Composition For any $X \mathrm{~s}$ if $\varphi$ holds of the $X$ s then there is some $z$ such that $z$ is a fusion of the Xs.

The final axiom of Composition is included for completeness since mereological theories typical include axioms that characterize under what conditions composition occurs. Here, I have simply used a schema, where $\varphi$ here can be any condition one likes: e.g. if $\varphi$ is just the condition that there is at least one of the $X s$ then the result will be mereological universalism, or $\varphi$ might be the more restrictive condition that the $X$ s are structured in a certain way, etc. Also, ' $z$ is a fusion of the $X \mathrm{~s}^{\prime}$ means 'for all $y, y$ overlaps $z$ if and only if $y$ overlaps one of the $X \mathrm{~s}$ '.

This theory has many models that allow for mutual parthood. We can draw these models using directed graphs, with letters at each node representing an object and arrows representing 
the parthood relation. (Chaining together arrows also counts as an instance of parthood.) A model of the statue and the clay, for example, might look like this:

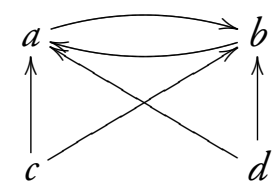

Here $a$ and $b$ are the statue and clay respectively, and $c$ and $d$ parts of both. ${ }^{23}$

Here is another model, this time of three objects, all of which are mutual parts of one another:

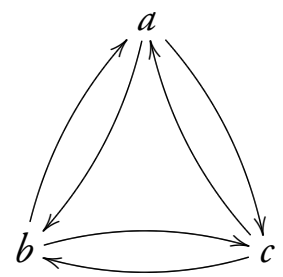

This last model is particularly salient for our purposes, since it purports to have the structure of the perichoretic relations between the persons of the Trinity. In each case, every person is part of another person who is in turn part of the first. We can see that every person is a mutual part of every other person of the Trinity.

These models show that the formal system is logically consistent; there is nothing contradictory about a relation that satisfies these axioms. And insofar as we are willing to accept that this axiomatic system represents a kind of containment conception of 'being in', we have shown that mutual 'being in' is formally coherent.

\section{Divine Simplicity}

In modeling perichoresis as a kind of parthood relation, the proposal would seem to run the risk of conflicting with the long-standing albeit controversial doctrine of divine simplicity. In this section I will outline six different versions of the doctrine of simplicity, and address each of them

\footnotetext{
${ }^{23}$ For convenience we are leaving aside the obvious possibility that $c$ and $d$ have other parts.
} 
in turn. I'll argue that on each construal, God can be considered to be simple even if we accept the mutual parthood model of perichoresis.

The doctrine of divine simplicity has too long of a history to outline here. Its foremost recent critic is Plantinga [84] (see also Mullins [77], Schmitt [93]). But the doctrine also has many recent proponents (Brower [I6], Davies [3 I], Dolezal [34], Leftow [65]). There are a number of different things one might mean by this doctrine, however. Consider:

I. God is simple by virtue of being immaterial; he has no material parts.

2. God is simple by virtue of transcending spacetime; he has no spatial or temporal parts.

3. God is simple by virtue of being identical to his attributes; he has no formal or qualitative parts.

4. God is simple by virtue of being undivided; his divinity is not split between the divine persons.

5. God is simple by virtue of being independent; he is not composed of anything more fundamental than himself.

6. God is simple by virtue of having no (proper) parts of any sort.

Each of these doctrines are distinct, with (6) being the most general formulation. I want to argue that all of them may be affirmed by those who accept our model.

Starting with (I), note that in modeling perichoresis as a parthood relation I have not made any assumption that God is made of matter nor that the parthood relation is restricted only to material objects. Regarding (2), given that I have not analyzed parthood in terms of spatial or temporal relations, there is no assumption here that God has spatial or temporal parts. Of course, spatial intuitions often drive judgements about 'containment' or 'being in', but it needn't be so (compare the examples in $\$ I .3$ ).Nothing about this analysis entails that all parts must be located in spacetime, and so there is no reason to think the view violates simplicity of type (2). 
As for (3), we come to the most controversial doctrine of simplicity: God's identity with his attributes. This version of simplicity is based on a background constituent ontology according to which attributes are themselves parts of the concrete particulars that instantiate them. Contrast relational ontology according to which attributes are not parts of the concrete things that instantiate them. ${ }^{24}$ If a constituent ontologist were to accept that God's attributes are distinct from himself (or from one another) then God would have distinct parts and hence would be metaphysically complex, violating simplicity. Relational ontologists can quite happily accept that God has no formal or qualitative parts, as they already accept that nothing concrete has such parts. ${ }^{25}$ As far as I can see, nothing about modeling perichoresis as a kind of parthood conflicts with (3), and so I will leave this thorny issue aside.

Now we turn to (4)-(6), the versions of divine simplicity that most directly threaten the current proposal. I will address each question in turn.

\section{I Distinction without Division}

The question raised by (4) is whether God is rightly thought to be divided or partitioned into the divine persons; the answer within classical theology has nearly always been in the negative. Consider the High Medieval theologian Peter Lombard:

Nor is any of the three persons a part of God or of the divine essence, because each of them is truly and fully God and is the whole and full divine essence and so none of these persons is a part of the Trinity. (Sententiarum, I, XIX, 5; in [66, vol. I, p. I08])

The idea here is that each person of the Trinity should not be thought of as a part of God, since in the ordinary setting that would imply that each person of the Trinity is not wholly or fully God. This is intuitively correct, as it appeals to the thought that where there are proper parts, there

\footnotetext{
${ }^{24}$ The connection between constituent and relational ontologies and the doctrine of simplicity was made first by Wolterstorff [I I3]. For more details on the metaphysics, see van Inwagen [I09].

${ }^{25}$ This is not to say that relational ontologists don't have any problems in giving an account of God's attributes, but whatever those problems are, they are not mereological.
} 
is a remainder. (Recall this is the same natural thought that lies behind various supplementation principles.) God is not divided in this sense.

In modeling perichoresis as a kind of parthood, one might wonder whether I have run afoul of this idea. Although the model only claims that the three persons of the Trinity are parts of each other, we also want to affirm that each person is God. Does this mean that God is divided amongst the persons? No. After all, each person is itself 'included in' every other person. When it is claimed that the Son is God, it is simply false that there are other parts of God not included within the Son. And this is precisely what our model of mutual indwelling secures. The Son is fully God and the fullness of God is 'in' him; that is, the entirety of the Trinity dwells in him.

Here is another way of illustrating the point. Consider again the relevant model of perichoresis:

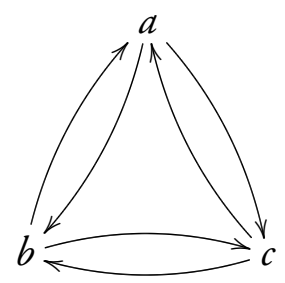

Which of the elements of this model is composed of the others? The answer is complicated by the fact that the composition relation here is not unique — that is, there are $X$ s such that more than one thing that counts as being a fusion of the $X$ s. In fact, since everything overlaps everything else in this model, every person counts as a 'fusion' of every collection of persons. The Father is composed of the Father, Son, and Spirit; the Son is composed of the Father, Son, and Spirit; and the Spirit is composed of the Father, Son, and Spirit as well. Because they all mutually interpenetrate one another, they are each 'composed' of all the others.

This situation should be sharply contrasted with another mereological model with three basic elements: 


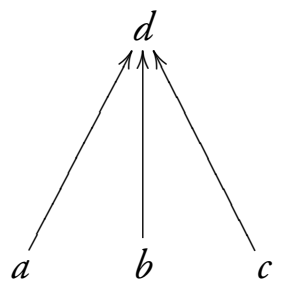

This model is strikingly different in that each of the three basic elements are composed into a fourth thing. That fusion is unique, and has each of its basic elements as proper parts. In this case, some fourth thing $d$ is divided among three others $a, b, c$; in this case, because $d$ has $a$ as a proper part, there is some remainder of $d$ that isn't included in $a$. This is not the model of the persons of the Trinity I am proposing; let me emphasize - I am not proposing that God is composed of the three persons of the Trinity, each of which is a proper part of God. To mistake this model for the one above would be to misunderstand the main contention of this paper: the mereological relation of mutual parthood can provide a coherent model of perichoresis; the mereological relation of composition, however, does not account for the unity or oneness of God.

\subsection{Dependence and Mutual Parthood}

Now to the question raised in (5): is God composed of anything more fundamental than himself? Consider Anselm:

For, everything which is composite requires for its subsistence the things of which it is compounded, and, indeed, owes to them the fact of its existence, because, whatever it is, it is through these things. (Anselm, Monologion XVII, in [2])

And Aquinas: ${ }^{26}$

On the contrary, every composite is posterior to its components: since the simpler exists in itself before anything is added to it for the composition of a third. But

\footnotetext{
${ }^{26}$ Compare Summa Theologica I.3.7 [4]: "Every composite thing is posterior to its components and dependent on them. But, as was shown above, God is the first being."
} 
nothing is prior to the first. Therefore since God is the first principle, He is not composite. (Aquinas, Scriptum super libros sententiarum I.8.4.I in [3, p. 93])

The reasoning here regards God's ontological priority over all other things. One of the main motivations for adhering to divine simplicity is aseity, the thought that God is not dependent on anything for his existence. It is frequently thought that composite objects are dependent on their parts for their existence. So God must be simple, lest he be dependent on his parts. ${ }^{27}$

This argument for simplicity depends, of course, on the independent premise that wholes depend or are grounded in their parts - a premise which has recently become extremely controversial. In recent metaphysics it has come under heavy attack on a number of independent grounds. Schaffer [92] has put forward a number of arguments for priority monism - the view that the whole universe is ontologically prior to its many parts — on the basis of physical ${ }^{28}$ and metaphysical ${ }^{29}$ considerations. Priority monism is a radical inversion of the usual part-whole dependence order. But recently it has been put in service of the doctrine of the Trinity to preserve aseity without simplicity (Fowler [44]).

Rather than purely inverting the order of dependence, others have simply denied that dependence and parthood correlate at all. Some argue that wholes depend on their parts whilst other wholes are prior to their parts; ${ }^{30}$ others suggest that the dependence can run either up or down the mereological hierarchy depending on the kind of part it is. ${ }^{31}$ Johnston [57] is explicit about the implications for divine simplicity:

In the tradition of Classical Theism, a paradoxical consequence has been drawn from this, namely that God is utterly simple, so that his essential attributes must all be identical, and be identical with him. [...] But these paradoxical conclusions only

\footnotetext{
${ }^{27}$ See Brower [17] and Morris [76] for more on the relation between the doctrines of divine simplicity and aseity.

${ }^{28}$ See also Calosi [r9].

${ }^{29}$ See also Cameron [20], Esfeld [40], Morganti [75], and Trogdon [104].

${ }^{30}$ See e.g. Inman [54] and McDaniel [73, p. 2I 2f].

${ }^{31}$ See McDaniel's [72] discussion of Armstrong, and especially the neo-Aristotelians e.g. Fine [43, \$9] and Johnston $\left[57, \$_{12}\right]$ who think that wholes depend on their 'constituent' or 'structural' parts (like the mechanical parts of a motorcycle), but whose 'decompositional' parts (like the Northern or Southern hemisphere) depend on the whole. See also Koons [62] and Marmodoro [70].
} 
follow given Thomas's false assumption that every composite thing is posterior to its components, and dependent on them. $([57$, p. 679])

So there is generally independent reason to doubt the crucial premise in the main argument for divine simplicity. A mereologically complex God need not be dependent on anything.

Such a defense is available to the view of mutual indwelling developed here. There are really two main options for those who accept a mutual parts mereology. The first is simply to deny that ontological dependence tracks mereological parthood. In fact, insofar ontological dependence is a kind of metaphysical explanatory relation, we may have even more reason to be suspicious. Mutual parts would entail a cycle of metaphysical explanation - a whole grounded in a part that is grounded in that whole — which may well be regarded as viciously circular (Lowe [68, 67]).

A second option would be simply to accept the correlation between parthood and ontological dependence, and simply accept that ontological dependence is not itself asymmetric (a principle which has itself recently become controversial viz. Barnes [9], Rodriguez-Pereyra [89]). If cases of mutual parthood are cases of symmetric dependence, one might well agree with Bliss [I 2] and Thompson [IOO] that symmetric dependence is not viciously circular. In the case of the Trinity, then, God would be a paradigm case of an ontologically interdependent entity without this violating God's aseity. Everything that is not God is dependent on God, whilst God is not dependent on anything that is not God, even if there can be mutual interdependence within the Trinity. ${ }^{32}$

Evaluating the metaphysical and theological merits of each response is for another time (though I prefer the first on metaphysical grounds). If either is successful, though, there is no deep conflict between my model of mutual indwelling and the the aseity of God.

\footnotetext{
${ }^{32}$ Some language used in describing the relations between the persons of the Trinity like 'begets' and 'proceeds from' suggests dependence relations in the Trinity. I do not think of the divine processions in this way, but how such language relates to aseity and ontological dependence is beyond the scope of this paper.
} 


\subsection{Two Definitions of Proper Parthood}

Let us turn now to the more general doctrine of simplicity raised in (6) - the claim that God has no proper parts of any sort. (Since God is self-identical he is an improper part of himself; so (6) must be phrased using the notion of proper parthood.) But how exactly should we understand proper parthood?

In mereology, there are two candidate definitions for proper parthood.

Proper Parthood I (PPI) $x$ is a proper part of $y$ iff $x$ is part of $y$ and $x$ is not identical to $y$

Proper Parthood 2 (PP2) $x$ is a proper part of $y$ iff $x$ is part of $y$ and $y$ is not part of $x$

While the former definition PPI is presumably more common, many authors have relied on the identity-free version PP2, following Goodman [50]. ${ }^{33}$ In classical mereology, the two definitions are equivalent: $\mathrm{PP}_{2}$ logically entails $\mathrm{PP}_{\mathrm{I}}$, but the converse entailment requires antisymmetry. So in the context of a mutual parts mereology the equivalence breaks down, and there are compelling reasons to prefer the second definition.

The first reason in favor of $\mathrm{PP}_{2}$ as the correct definition for proper parthood concerns the transitivity of proper parthood. Proper parthood should be transitive if parthood is, but this occurs only on PP2. PPI allows violations of transitivity, as in the following countermodel.

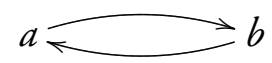

If $a$ is a proper part of $b$ and $b$ is a proper part of $a$, it will not follow that $a$ is a proper part of $a$ as that would contradict PPI.

A second reason to favor $\mathrm{PP}_{2}$ as the correct definition for proper parthood is that it, but not PPI, is compatible with Supplementation. Recall (from $\$ 2 . \mathrm{I}$ ) that any object that has a proper part must have another part disjoint from the first. The principle is extremely intuitive; so natural

\footnotetext{
${ }^{33}$ Examples include Casati and Varzi [2 I, p. 36], Eberle [36], Niebergall [78, p. 338], [79, p. 274], and Simons [97, p. 286].
} 
in fact that many authors have gone so far as to call it analytically true. ${ }^{34}$ But it would be false on the PPI definition: the same countermodel as above can be used. If $a$ and $b$ are mutual parts, then $a$ is a proper part of $b$ on the PPI definition. But by transitivity every part of $b$ is a part of $a$ and hence there can be no proper parts of $b$ that do not overlap $a$. This sort of situation does not arise with $\mathrm{PP}_{2}$, however, since no mutual parts are ever proper parts on the $\mathrm{PP}_{2}$ definition.

This last fact is important, since according to the $\mathrm{PP} 2$ definition an entity that has nothing but mutual parts will have no proper parts. To be a simple is to have no proper parts, and hence entities like $a$ and $b$ in the above model count as simples. The same holds true, of course, in the three-element model of perichoresis. Each person of the Trinity has no proper parts (given the only plausible definition), and hence each is mereologically simple. ${ }^{35}$

One might object: doesn't this accommodation of divine simplicity undermine our original claims that the Father is in the Son and the Son is in the Father? Can't we make a similar distinction between 'being in' and 'being properly in' on analogy with the $\mathrm{PP} 2$ definition? And if we do, wouldn't it follow that the Father is not properly in the Son, and the Son is not properly in the Father?

In short, yes, these definitions are available and they do have these consequences. I do not agree that this undermines our aims, however. Claims of 'being properly in' were not the perichoretic claims to be modeled. Moreover, we should not affirm that the Father is properly contained in the Son, nor vice versa, precisely because we do not have the requisite supplementation intuition regarding the Trinity — there is no 'remainder' of the Father without the Son, nor is there any

\footnotetext{
${ }^{34}$ Varzi [I Io, p. I Io] claims 'This principle expresses a minimal requirement which any relation must satisfy [...] if it is to qualify as parthood at all.' Simons [96, p. I I6] claims that '[Supplementation] is indeed analytic-constitutive of the meaning of proper part'. Similar claims to analyticity are endorsed by Bohn [13, p. 27 footnote 3], Koslicki [63, p. I67-I68], and McDaniel [72, p. 264].

${ }^{35}$ This raises the question of whether any person of the Trinity has any non-mutual parts; for example, an anonymous referee wondered whether the Son has his human nature as a proper part. As I think of natures as properties, and because I reject constituent ontology, the human nature of Jesus is not one of his parts. What about other material parts, e.g. the hands and feet of Jesus? These bodily parts should count as proper parts in the ordinary sense, but it's not clear in general how material parthood relations within the body of Jesus as incarnate Son will integrate with claims about the Trinity. For example, we wouldn't want to conclude that God has material parts from the claims that Jesus is God and Jesus had material parts. Nor will we want to conclude that God has proper parts mutatis mutandis. In any case, these are interesting issues I hope to write about in future work.
} 
'remainder' of the Son without the Spirit, etc. ${ }^{36}$ Mutual indwelling, on the mereological model, allows for parthood among distinct individuals without division or remainder.

\section{A Disanalogy: Distinctness and Separability}

As a model, I think the mereological conception of perichoresis can do some important philosophical and theological work. However, as with any model, there will be disanalogies. In this section I discuss one particular disanalogy between the motivating examples (e.g. the statue and the clay) and mutual indwelling of the divine persons related to the unity of the Trinity. I conclude by considering some ways of accounting for this unity, including modal inseparability and constitution.

The key disanalogy concerns the whether the persons of the Trinity are separable, i.e. whether any of the persons can exist without any of the others. Augustine thought this inseparability was a straightforward consequence of simplicity: "It is for this reason then that the nature of the Trinity is called simple, because it has not anything which it can lose [...]" (Augustine, City of God, Bk. I0, in [5, p. 319]). Even in the earliest uses of person-perichoresis for the doctrine of the Trinity, the persons were thought to be inseparable.

The abiding and resting of the Persons in one another is not in such a manner that they coalesce of become confused, but, rather, so that they adhere to one another, for they are without interval between them and inseparable [...]" (John Damascene, The Orthodox Faith, I.I 4.I I-I 8, in [29, p. 202])

Now, there are a number of different kinds of inseparability: it may be humanly impossible to separate two magnets of a certain strength, or it may be physically impossible to separate time and space, or it might be metaphysically impossible to separate the triangular from the trilateral, or

\footnotetext{
${ }^{36}$ If one really wanted to insist that proper indwelling is the correct perichoretic notion, there are at least two avenues to capture that thought. First, one could simply opt for the PPI notion of proper parthood, and would then have to reject transitivity and supplementation (which shouldn't hold in the case of the persons of the Trinity anyway). Second, one could follow Cotnoir and Bacon [24] and axiomatize proper parthood directly as merely a transitive relation. On this route, only Strong Supplementation can be maintained, and entities can be proper parts of themselves.
} 
logically impossible to separate the truth of a proposition from the truth of its double-negation. The key question for separability is this: to what extent is it possible (on some understanding of the relevant modality) for one to exist without the other?

The persons of the Trinity, as co-eternal, are temporally inseparable; similarly, as metaphysically necessary they are metaphysically inseparable. By contrast, the statue and clay are clearly separable: one can exist without the other. The clay is typically made before a statue. There might be worlds like ours in which the very same clay exists but no statue was made, or worlds very similar to ours in which that particular portion of clay didn't exist and so the same statue was made from a different portion. As a result, three persons of the Trinity are more strongly united than the statue and the clay, and hence mutual parthood is not sufficient to account for this unity.

This is something of a drawback for the model, as perichoresis is typically intended to function as a means of uniting the persons of the Trinity. Of course, one can accept the metaphysical impossibility of their separability, by dint of their necessary existence. But this inseparability is not due to perichoresis; their unity is not explained by their mutual indwelling.

There are some kinds of unity that can be accounted for by parthood, as parthood is a significantly intimate relation. Sider [94, p. 70] outlines two key ways in which that intimacy shows up. ${ }^{37}$

Inheritance of Location If $x$ is part of $y$, then $y$ is located wherever $x$ is located.

Inheritance of Intrinsicality If property $P$ is intrinsic, then the property having a part that has $P$ is also intrinsic.

The Inheritance of Location entails mutual parts will have to be co-located; and this corresponds to a robust notion of spatial inseparability. Of course this only holds for parts that have locations, and I've already questioned whether this is appropriate for the divine persons in $\$$ I.I. The Inheritance of Intrinsicality entails every intrinsic property of a part (' $P$ ') will correspond to an intrinsic property of the whole ('having a part that has $P^{\prime}$ ), and for mutual parts vice versa. The import of

\footnotetext{
${ }^{37}$ See also Gilmore [46] for discussion.
} 
this inheritance principle for the divine persons is that the intrinsic properties of each person of the Trinity (e.g. 'being begotten') correspond to some other property (e.g. 'being such that the begotten dwells within me') intrinsic to every other person of the Trinity.

While these notions of intimacy and unity may well be philosophically and theologically important; it should be clear enough that they cannot carry the whole weight of the unity of the Trinity.

\section{I Constitution and Separability}

There is at least one other sense in which mutual parts are united that is worth highlighting: in the usual material examples, mutual parts are united by being made of the same matter.

One main rival to the mutual parthood view makes heavy use of this shared matter: it's the view that the statue is constituted by the clay. Many, following Aristotle, hold to a hylomorphic view of material objects such that the matter (e.g. the clay) is part of the whole (e.g. the statue), though not vice vers ${ }^{38}$ Such a view accepts the numerical distinctness of the statue and the clay, but they do not typically accept anti-extensionalism. ${ }^{39}$ That is because hylomorphic views generally accept that there are parts (or perhaps 'constituents') of the statue, namely its form, that distinguish it from the clay.

To be clear, this is not the view I am defending here. I do not accept that there are formal parts (or constituents) that serve to mereologically distinguish the statue and the clay; they are distinguished by their properties and properties are not parts. Nor do I here undertake a commitment to a basic metaphysical relation of constitution that holds asymmetrically between the statue and the clay.

The constitution view of material objects has been put forth (by Brower and Rea [I8]) as a model of the metaphysics of the Trinity. ${ }^{40}$ Imagine a clay statue is used as a pillar in a cathedral.

\footnotetext{
${ }^{38}$ See Fine [42], Haslanger [53], Koslicki [63], and Rea [87, 88].

${ }^{39}$ Some theorists accept a constitution relation without understanding constituting matter as a part. See e.g. Baker [7, 8].

${ }^{40}$ See also Hasker [52, ch. 28$]$ for a somewhat different constitution model.
} 
Just as the statue and pillar are numerically distinct but made of the same material stuff (the clay), so too can the Father, the Son, and the Spirit be numerically distinct but made up of the same immaterial stuff (the divine essence). But just as the statue and the pillar are (in some sense or other) 'the same material object', so too are the Father, Son, and Spirit 'the same immaterial object'. Instructive as it may be, the constitution view of the Trinity has faced a number of criticisms. $^{41}$

From the perspective of the aims of this paper, it is not immediately obvious how the constitution model can make sense of mutual indwelling. Though the persons are the 'same' in an important sense, there is no clear sense in which they are 'in' one another. One potential avenue is as follows: one could make use of a predicational concept of 'being in', in particular the relation of instantiation. Each person of the Trinity instantiates the divine essence, and hence this essence is 'present in' each person. By itself, this doesn't quite deliver mutual indwelling between the persons, but only a shared essence. To supplement, one might suggest that a kind of systematic ambiguity thesis: so when Jesus says "I am in the Father and my Father is in me" what is meant is that "I [my essence] is in the Father [the person] and the Father [his essence] is in me [the person]." This delivers an interpretation of the target perichoretic claims, but seems to me to be something of a stretch, however. Alternatively, one could accept (perhaps by divine simplicity) that each person is identical to the divine essence. If essences are still said to be 'present in' the persons they are identical to, this would deliver the truth of the perichoretic claims. In this case, though one wonders how material constitution sheds any light on the underlying metaphysics.

While I think Brower and Rea are right to look for some kind of sameness without identity, I do not think constitution is the right sort of notion. Sameness of matter (or 'immaterial stuff') is not sufficient for two things to count as the same material object, because it is not sufficient for inseparability. The statue and the pillar are clearly separable: one can exist without the other temporally and modally, even though they are constituted by the same matter. The statue might be removed from the plinth in the cathedral and placed in a museum, thus ceasing to be a pillar

\footnotetext{
${ }^{41}$ See Craig [27], Hasker [5I], and Tuggy [106].
} 
whilst remaining a statue. Or, the sculptor might be unhappy with the shape of statue, and so take it down and reform the very same clay into a pure cylindrical pillar, whereby the statue ceases to exist. It seems natural to think that the degree to which one can exist without the other informs our judgements about whether one thing is the same object as another. So in what sense do they count as the same material object? ${ }^{42}$ In sum, neither constitution nor mutual parthood is sufficient to account for this deep metaphysical unity.

It is worth contrasting the aims of this paper with the aims of Brower and Rea [I 8]. They set out to provide a metaphysically perspicuous model of 'sameness without identity' to help explain how the three persons of the Trinity can be one God. My aims were much more modest; I didn't set out to solve all philosophical difficulties with the doctrine of the the Trinity. I merely wished to solve the puzzle as to how any reasonable conception of being in could allow us to make sense of mutual indwelling. In my view, Brower and Rea are right that the puzzles of material constitution can illuminate the Trinity, but not in the way that they suppose.

\subsection{Unity and Oneness}

I still have not delivered a fully adequate model of divine unity; and as a result, we have not given a full account of the doctrine of the Trinity. We should not rest content with a mere 'social' model of three persons that mutually indwell one another; critics of social trinitarianism may well be right that perichoresis alone cannot account for the unity of the three persons. The doctrine of the Trinity requires us to make sense of a deep metaphysical oneness of God. After all, almost immediately after Jesus expresses his mutual indwelling with the Father, he claims "I and the Father are one" (John I0:30). In the words of Augustine:

There are the Father, the Son, and the Holy Spirit, and each is God and at the same time all are one God; and each of them is a full substance, and at the same time all

\footnotetext{
${ }^{42}$ Of course this sort of coming-into and going-out-of existence is impossible with the Father, Son, and Spirit as they are (arguably) necessary existents. But that can't be the whole story of their unity; after all, we do not think of, say, the number 3 and the Father as united simply because they are both necessary existents.
} 
are one substance. (Augustine, On Christian Doctrine I.5.5, in [6, p. Io])

I have been assuming throughout that the persons of the Trinity are distinct, i.e. non-identical. This is in part because trinitarian monotheism requires one to affirm that there are three divine persons. But it also follows from the Indiscernibility of Identicals: there are truths about each person that are not true of the others. So we cannot, I think, ensure the oneness of the persons by identity.

What is required, then, is a metaphysics of unity that is not tied to qualitative indiscernibility. Of course, this is nothing more than a pointer in a certain direction. A fully worked out model of the doctrine of the Trinity is a long way off. But providing a conceptually coherent model of mutual indwelling is a good start. ${ }^{43}$

\section{References}

[I] P. Aczel. Non-Well-Founded Sets. CSLI Publications, Stanford, CA, I 988.

[2] Saint Anselm. Monologion. In Proslogium; Monologium: An Appendix In Behalf Of The Fool By Gaunilo; And Cur Deus Homo,. The Open Court Publishing Company, Chicago, I929.

[3] Thomas Aquinas. Thomas Aquinas's Earliest Treatment of the Divine Essence: 'Scriptum super libros Sententiarum,'Book I, Distinction 8. Episteme: Medieval Studies Worldwide. SUNY Press, I998.

[4] Thomas Aquinas. Summa Theologiae. Cambridge University Press, Cambridge, 2006. Edited by T. Gilby; Eng. trans. by T. McDermott.

[5] Saint Augustine. The City of God. Hendrickson Publishers, 2009.

[6] St Augustine. On Christian Doctrine. Bobs-Merrill, Indianapolis, I958.

[7] Lynne Rudder Baker. Why constitution is not identity. Journal of Philosophy, 94:599-62 I, I997.

\footnotetext{
${ }^{43}$ Work on this article was generously supported in the form of a Summer Stipend by the Classical Theism Project at the University of St. Thomas (MN) and the John Templeton Foundation. This paper has been informed by many discussions with colleagues and friends over the last several years; to attempt to list them all would surely be folly. Thanks especially to two anonymous referees for this journal for their careful and helpful comments.
} 
[8] Lynne Rudder Baker. Unity without identity: A new look at material constitution. Midwest Studies in Philosophy, 23(I): I 44-165, I999.

[9] Elizabeth Barnes. Symmetric dependence. In Ricki Bliss and Graham Priest, editors, Reality and Its Structures. Oxford University Press, forthcoming.

[ı。] J. Barwise and L. Moss. Vicious Circles. On the Mathematics of Non-Well-Founded Phenomena. CSLI Publications, Stanford, CA, 1996.

[I I] Joseph Blatti. Material constitution. In Neil A. Manson and Robert W. Barnard, editors, The Continuum Companion to Metaphysics, pages I 49-169. Continuum, New York, 2012.

[1 2] Ricki Bliss. Viciousness and circles of ground. Metaphilosophy, 45(2):245-256, 20 I4.

[13] E. D. Bohn. An argument against the necessity of unrestricted composition. Analysis, 69(I):27-3I, 2009.

[14] Einar Duenger Bohn. The logic of the Trinity. Sophia, 50(3):363-374, 201 I.

[1 5] J. L. Borges. El aleph. In Elaleph. Losada, Buenos Aires, I 949. Eng. trans. by A. Kerrigan: The Aleph. A Personal Anthology, Grove, New York, 1967.

[16] Jeffrey E. Brower. Making sense of divine simplicity. Faith and Philosophy, 25, 2008.

[17] Jeffrey E. Brower. Simplicity and aseity. In Thomas P. Flint and Michael C. Rea, editors, The Oxford Handbook of Philosophical Theology, pages I05-28. Oxford University Press, 2009 .

[i 8] Jeffrey E. Brower and Michael C. Rea. Material constitution and the Trinity. Faith and Philosophy, 22(I):57-76, 2005.

[19] Claudio Calosi. Quantum mechanics and priority monism. Synthese, (5):I-I4, 20 I 3.

[20] Ross P. Cameron. From Humean truthmaker theory to priority monism. Nồs, 44(I):I $78-$ I 98,20 IO.

[2 I] Roberto Casati and Achille C Varzi. Parts and Places: The Structures of Spatial Representation. MIT Press, Cambridge, MA, I999.

[22] A. J. Cotnoir. Strange parts: The metaphysics of non-classical mereologies. Philosophy Compass, 8(9):834-845, 2013.

[23] A. J. Cotnoir. Does universalism entail extensionalism? Nô̂s, 50:I 2 I-I 32, 2016.

[24] A. J. Cotnoir and Andrew Bacon. Non-wellfounded mereology. Review of Symbolic Logic, 5(2): I $87-204,20 \mathrm{I} 2$.

[25] A. J. Cotnoir and D. L. M. Baxter, editors. Composition as Identity. Oxford University Press, Oxford, 2014. 
[26] Aaron J. Cotnoir. Anti-symmetry and non-extensional mereology. Philosophical Quarterly, 60(239):396-405, 2010.

[27] William Lane Craig. Does the problem of material constitution illuminate the doctrine of the Trinity? Faith and Philosophy, 22(I):77-86, 2005.

[28] Oliver Crisp. Problems with perichoresis. Tyndale Bulletin, 56(I):I I9-I40, 2005.

[29] John Damascene. The orthodox faith. In St. John of Damascus, Writings, The Fathers of the Church. The Catholic University of America Press, I999.

[30] Paul R. Daniels. Occupy wall: A mereological puzzle and the burdens of endurantism. Australasian Journal of Philosophy, 92(I):9I-IO I, 2014.

[3 I] Brian Davies. A modern defence of divine simplicity. In Brian Davies, editor, Philosophy of Religion: A Guide and Anthology, pages 549-64. Oxford University Press, Oxford, 2000.

[32] Stephen T. Davis. Perichoretic monotheism: A defense of a social theory of the Trinity. In M. Y. Stewart (ed.), editor, The Trinity: East/West Dialogue, pages 35-52. Kluwer, Boston, 2003.

[33] Stephen T. Davis. Christian Philosophical Theology. Oxford University Press, New York, 2006.

[34] James E. Dolezal. God Without Parts: Divine Simplicity and the Metaphysics of God's Absoluteness. Pickwick, $20 \mathrm{I}$ I.

[35] A. Eagle. Location and perdurance. Oxford Studies in Metaphysics, 5:53-94, 2010.

[36] R. A. Eberle. Nominalistic Systems. Kluwer, Dordrecht, I970.

[37] N. Effingham. Mereological explanation and time travel. Australasian Journal of Philosophy, $88: 333-345$, 2010.

[38] N. Effingham and J. Robson. A mereological challenge to endurantism. Australasian Journal of Philosophy, 85:633-640, 2007.

[39] Herbert B. Enderton. Elements of Set Theory. Elsevier, I977.

[40] Michael Esfeld. Physicalism and ontological holism. Metaphilosophy, 30(4):3 I9-337, I999.

[4I] Kit Fine. The non-identity of a material thing and its matter. Mind, I I 2(446):195-234, 2003.

[42] Kit Fine. Coincidence and form. Proceedings of the Aristotelian Society, Supplementary Volume, 82(I):IOI-I I 8, 2008.

[43] Kit Fine. Towards a theory of part. Journal of Philosophy, I07:559-589, 20 I0. 
[44] Gregory Fowler. Simplicity or priority. In J. Kvanvig, editor, Oxford Studies in Philosophy of Religion, volume 6, pages I I 4-37. Oxford University Press, 20 I 5.

[45] C. Gilmore. Coinciding objects and duration properties: Reply to Eagle. Oxford Studies in Metaphysics, 5:95-I I I, 20 IO.

[46] C. Gilmore. Sider, the inheritance of intrinsicality, and theories of composition. Philosophical Studies, I 5 I:177-97, 2010.

[47] C. Gilmore. Parts of propositions. In S. Kleinschmidt, editor, Mereology and Location, pages I 56-208. Oxford University Press, Oxford, 2014.

[48] C. Gilmore. Quasi-supplementation, plenitudinous coincidentalism, and gunk. In R. Garcia, editor, Substance: New Essays. Philosophia Verlag, Munich, 2015.

[49] Cody Gilmore. Time travel, coinciding objects, and persistence. Oxford Studies in Metaphysics, 3:177-198, 2007.

[50] N. Goodman. The Structure of Appearance. Harvard University Press, Cambridge, MA, I95I.

[5I] William Hasker. Constitution and the Trinity. Faith and Philosophy, 27(3):32 I-329, 20 Io.

[52] William Hasker. Metaphysics and the Tri-personal God. Oxford University Press, Oxford, 2013.

[53] Sally Haslanger. Parts, compounds, and substantial unity. In T. Scaltsas, D. Charles, and M. L. Gill, editors, Unity, Identity, and Explanation in Aristotle's Metaphysics, pages I 29-70. Clarendon Press, Oxford, I994.

[54] Ross Inman. Substantial Priority: An Essay in Fundamental Mereology. PhD thesis, 2013.

[55] Ross Inman. Omnipresence and the location of the immaterial. In Oxford Studies in the Philosophy of Religion. Oxford University Press, Oxford, forthcoming.

[56] Mark Johnston. Constitution is not identity. Mind, I0 I:89-105, I992.

[57] Mark Johnston. Hylomorphism. Journal of Philosophy, 103:652-698, 2006.

[58] Nicholaos John Jones. Mereological heuristics for Huayan buddhism. Philosophy East and West, 60(3):355-368, 20 Iо.

[59] Karen Kilby. Perichoresis and projection: Problems with social doctrines of the trinity. New Blackfriars, 8 I:432-445, 2000.

[6o] S. Kleinschmidt. Multilocation and mereology. Philosophical Perspectives, 25:253-276, 20 II. 
[6I] Shieva Kleinschmidt. Many-one identity and the Trinity. Oxford Studies in Philosophy of Religion, 4:84-96, $20 \mathrm{I} 2$.

[62] Robert Koons. Staunch vs. faint-hearted hylomorphism: Toward an aristotelian account of composition. Res Philosophica, 91:I-27, 2014.

[63] Kathrin Koslicki. The Structure of Objects. Oxford University Press, Oxford, 2008.

[64] Brian Leftow. Is God an abstract object? Nô̂s, 24.(4):58 I-98, I990.

[65] Brian Leftow. Divine simplicity. Faith and Philosophy, 23:365-380, 2006.

[66] Peter Lombard. The Sentences. Pontifical Institute of Medieval Studies, Toronto, 200720Io. Eng. trans. by G. Silano.

[67] E. J. Lowe. Ontological dependence. In Edward N. Zalta, editor, The Stanford Encyclopedia of Philosophy. 2009.

[68] E.J. Lowe. Ontological dependency. Philosophical Papers, 23(I):3 I-48, I 994.

[69] Ofra Magidor. Arguments by Leibniz's law in metaphysics. Philosophy Compass, 6(3):I 80I95, 20 II.

[70] Anna Marmodoro. Aristotle's hylomorphism, without reconditioning. Philosophical Inquiry, 36:5-22, 2013.

[71] J. Mascaró, editor. The Upanishads. Penguin, London, I965.

[72] K. McDaniel. Structure-making. Australasian Journal of Philosophy, 87:25 I-274, 2009.

[73] Kris McDaniel. The Fragmentation of Being. Oxford University Press, forthcoming.

[74] Trenton Merricks. Propositions. Clarendon Press, Oxford, 2015.

[75] Matteo Morganti. Ontological priority, fundamentality and monism. Dialectica, 63:27 I288,2009 .

[76] Thomas V. Morris. Dependence and divine simplicity. International Journal for Philosophy of Religion, 23, I988.

[77] Ryan T. Mullins. Simply impossible: A case against divine simplicity. Journal of Reformed Theology, 7:1 $8 \mathrm{I}-203,20 \mathrm{I} 3$.

[78] K. Niebergall. Calculi of individuals and some extensions: An overview. In A. Hieke and H. Leitgeb, editors, Reduction, Abstraction, Analysis. Proceedings of the 3Ith International Wittgenstein Symposium, pages 335-354. Ontos, Frankfurt, 2009.

[79] K. Niebergall. Mereology. In Leon Horsten and Richard Pettigrew, editors, The Continuum Companion to Philosophical Logic, pages 27 I-298. Continuum, New York, 20 I I. 
[80] Ludwig Ott. Fundamentals of Catholic Dogma. Tan, Rockford, Illinois, I960.

[8I] Randall Otto. The use and abuse of perichoresis in recent theology. Scottish Journal of Theology, 54:366-84, 2001.

[82] Josh Parsons. Theories of location. Oxford Studies in Metaphysics, 3:20I-232, 2007.

[83] L.A. Paul. The puzzles of material constitution. Philosophy Compass, 5:579-590, 20 Io.

[84] Alvin Plantinga. Does God Have a Nature? Marquette University Press, I980.

[85] G. L. Prestige. $\pi \epsilon \rho \iota \chi \omega \rho \epsilon \omega$ and $\pi \epsilon \rho \iota \chi \omega \rho \eta \sigma \iota \zeta$ in the fathers. Journal of Theological Studies, I I $5(29): 242-52$, I 928.

[86] Graham Priest. One, Being an Investigation into the Unity of Reality and of its Parts, including the Singular Object which is Nothingness. Oxford University Press, Oxford, 20 I 4.

[87] Michael C Rea. Sameness without identity: An Aristotelian solution to the problem of material constitution. Ratio, I I:3 I6-328, 1998.

[88] Michael C. Rea. Hylomorphism reconditioned. Philosophical Perspectives, 25(I):34I-358, 2 OII.

[89] Gonzalo Rodriguez-Pereyra. Grounding is not a strict order. Journal of the American Philosophical Association, I (3):5 I 7-534, 20 I 5.

[90] David H. Sanford. The problem of the many, many composition questions, and naïve mereology. Noûs, 27(2):2 19-228, June I993.

[9I] Philip Schaff and Henry Wace, editors. Nicene and Post-Nicene Fathers, Vol. 9: Hilary of Poitiers, John of Damascus. Scribner, New York, I 899.

[92] Jonathan Schaffer. Monism: The priority of the whole. Philosophical Review, I 19:3 I-76, 2010.

[93] Yann Schmitt. The deadlock of absolute divine simplicity. International Journal for Philosophy of Religion, 74(I):I I 7-I 30, 2013.

[94] T. Sider. Parthood. Philosophical Review, I I 6:5 I-91, 2007.

[95] Theodore Sider. Four-Dimensionalism: An Ontology of Persistence and Time. Clarendon Press, Oxford, $200 \mathrm{I}$.

[96] Peter M Simons. Parts: A Study In Ontology. Clarendon Press, Oxford, I987.

[97] Peter M Simons. Free part-whole theory. In K. Lambert, editor, Philosophical Applications of Free Logic, pages 28 5-306. Oxford University Press, New York, I991.

[98] D. Smith. Mereology without weak supplementation. Australasian Journal of Philosophy, $87: 505-5$ II, 2009. 
[99] Richard Swinburne. The Christian God. Oxford University Press, Oxford, I993.

[ıоo] Naomi Thompson. Metaphysical interdependence. In Mark Jago, editor, Reality Making. Oxford University Press, 2016.

[IоI] J. J. Thomson. Parthood and identity across time. Journal of Philosophy, 80(4):20 I-220, April 1983.

[I02] J. J. Thomson. The statue and the clay. Nô̂s, 32(2):I 49-I73, June 1998.

[103] C. Tillman and G. Fowler. Propositions and parthood: The universe and antisymmetry. Australasian Journal of Philosophy, 90:525-539, 2012.

[1 04] Kelly Trogdon. Monism and intrinsicality. Australasian Journal of Philosophy, 87(I):I 27I 48,2009 .

[105] Dale Tuggy. The unfinished business of Trinitarian theorizing. Religious Studies, 39:165$83,2003$.

[106] Dale Tuggy. Constitution Trinitarianism. Philosophy and Theology, 25(I):I29-I62, 20 I 3.

[107] Charles C. Twombly. Perichoresis and Personhood: God, Christ, and Salvation in John of Damascus. Pickwick Publications, 2015.

[108] Peter van Inwagen. And yet there are not three gods but one God. In Thomas V. Morris, editor, Philosophy and The Christian Faith, pages 24I-78. University of Notre Dame Press, Notre Dame, Indiana, 1988.

[ 1 09] Peter van Inwagen. Relation vs. constituent ontologies. Philosophical Perspectives, 25, 20 I I.

[ I I o] Achille C Varzi. The extensionality of parthood and composition. Philosophical Quarterly, 58:108-I33, 2008.

[I I I] Ryan Wasserman. Material constitution. In Edward N. Zalta, editor, The Stanford Encyclopedia of Philosophy. Spring 2015.

[I I 2] C. F. J. Williams. Neither confounding the persons nor dividing the substance. In Alan G. Padgett, editor, Reason and the Christian Religion: Essays in Honour of Richard Swinburne. Clarendon Press, Oxford, I994.

[I I3] Nicholas Wolterstorff. Divine simplicity. Philosophical Perspectives, 5:53 I-52, I99I.

[I I4] Stephen Yablo. Parts and differences. Philosophical Studies, I73:I4I-I 57, 2016. 